\title{
Impact of monetary policies on exchange rate and global trade Evidence from Ghana
}

\author{
Rabnawaz Khan ${ }^{1 *}$ \\ ${ }^{1}$ School of Finance and Economics, Jiangsu University, Zhenjiang, Jiangsu, Zhenjiang \\ 212013, People's Republic of China.khan.rab@stmail.ujs.edu.cn
}

The impact of monetary policies and their implementation by exchange rate covered the economic condition of Ghana. The social inclusion and conversion factors change the implemented policies of nations, where the real price, trade, technology, a price rate and price level of ratio take an important part of growth. The reform of the financial sector favors the free floating of the exchange rate and global trade by under the premise of flexible exchange rates. The tragedy of country growth and exchange rate toward a trajectory of growth with the growth-enhancing effect through social inclusion, conversion factors, price level ratio, exchange rate, merchant rate, export and trade services. The research study is based on secondary study and social inclusion equity indicators with public resources, building human resources and social protection for economic development has determined. The monetary policies are classified by the different evidence and trade indicators. The significant influence of growth and internal policies has affected trade and exchange rates with growth and reserve policies. The results have computed by linear regression and it proved that social inclusion and alternative conversion factors impact on the global trade and create short term binary relationship.

Keywords: Trade; conversion factors; price rate; economic growth

\section{Introduction}

The main aims of this study paper are to examine the importance of monetary policies and their implication on the growth level with exchange rate, which showed by the trade, conversion factor, a price rate, and the growth level of GDP. The economic growth in Ghana determines the two different policies of patents and promoting. 30\% Ghanaians deal with the financial sectors and hold the big flow of financial circumstance, will this effect on monetary policies and or just creating the big gap in economic principle. There are two macroeconomic policies implemented to control government budgets and financial flow. Such as fiscal and metering policy, that can use economic manager to control the budgeting and fiancé.(Khanna, Greener, Straka, \& Adams, 2019) The health of fiancé to manage by expanding economic growth (GDP). The monitoring and fiscal policies are complementary with each other in Ghana. The monitoring polices are being a work by a civil society along with the strengthen policy program and strategies.(Agusto\& Khan, 2018; Ahmed et al., 2020) . 
The insight policies and an agenda based on trade and fiscal policies. Its advance to understanding the policy agenda and trade sector pregame in Ghana. And also, to determine the agenda of sector programs which influenced by how the national income level use their sources of power to define the material of fiscal policies.(Adu, Marbuah, \& Mensah, 2013) The power sources identified the structural authority; access by political influence, control, conversion factor, trade implementation, demographic change plan of trade,(Lin \& Agyeman, 2019; Uddin, Sjö, \& Shahbaz, 2013)The policies should not pursuit of transformative changes and improvement of economic system by low income countries. According to Rochefort the frame of label issues of economic decision has an influence on trade, a price rate in the economic development.(Kong \& Khan, 2019) The policy agenda setting and planning the subsequent issues labeling and policy sector with particular problem.(Bond, Söderbom, \& Wu, 2011; Mensah \& Botchway, 2013)

The important of this research paper is showing the basic monetary policies under the state of social inclusion, conversion factors, economic growth and global trade. However, prior research papers discussed the issues of global trade in a term of long term but not directly classify the issues of monetary policies under the above indicators, therefore this research study based on novelty.(Murtazashvili, Murtazashvili, \& Salahodjaev, 2019; Traoré, 2019) The research data based on World Bank indicators and also financial department of Ghana. $2^{\text {nd }}$ section of a research paper is based on literature and expect theories. We base 3rd section on research method and $4^{\text {th }}$ is an analysis and last one shows the recommendation and conclusion of the research paper.

\section{Literature}

The prior work of research showed the financial development-economic growth with extensive attention in the development and also have analysed the finance-led growth hypothesis with a content of cal-innovation through the efficient allocation of resources from the trade and unproductivity sectors.(Adu et al., 2013) The development of robust financial factors can spur growth and services with nonfinancial sectors along a growth path. The content of this economics growth based on trade and implemented economic policies and financial sectors, and thus development financial sectors focuses on the efficiency of trade and monitoring policies.(Amri, 2017) The financial development and efficiency of investment is important for financial liberalisation in promoting domestic and hence investment. The works of foundation for liberalisation and developing countries including Ghana, as part of the IMF bank change program.(Herrerias, Cuadros, \& Luo, 2016)

We must emphasize it that variant argument has been an advance in literature between economic growth and financial development.(Acheampong \& Maryudi, 2020) The empirical studies in the literature have investigated the relationship 
between financial depth and growth with the impact of causality. The most studies across on the panel data affirm the fact that financial development influence on growth and covariates of growth and the potential simultaneity, and unobserved country specific growth. Likewise, the 71 countries period 1960-1995 using indicators of financial development by regarding different expects of trade and monitoring policies.(Adom \& Kwakwa, 2014) The conclude on the positive influence between financial development on the economic growth with trade and implication of a change in policies and strategies with global tradition change.

The non-tradable sector effect on the currency and different price issues similar to an export subsidy and import of tax by the foreign ministry of Ghana. We illustrate the literature from the great part of the exchange rate and the consequence of a different way of investment. There are several issues of relationship between exchange rate and export value with misalignment and international trade. Hence, the part of the undervaluation of the exchange rate is different investing from which do not fully adjust their price of evolution of the exchange rate. The vertical integration and importer currency network of large shape in trade and investment. The final issue of the relationship between exchange rate and investment with trade and explored the effects of exchange with decision foreign ministry, especially they influence the investment rate and trade value of international trade. The prior research study is also showed the limited and largely focused contingency in the long period of overvalued.

The trade policy may compensate for the different levels of currency and domestic firm exchange rate and lose competitiveness because of the exchange rate and an overvalued currency. The dispute of the exchange rate policies among trade partners creates the relationship between trade and investment. In more general, the countries use trade and substitute for the exchange rate with persistent disequilibria in a trade of business and investment. This paper main finding showed the exchange rate with a vitality which is does not affect international trade except in the occurrence of union and pegged exchange and trade rate in international market, the rate is not directly covert the country monitoring policy in the long term, its effect on the short term but the economy directly volatility the trade and investment for the long term. Second the currency directly flow the relationship of exchange rate and pegged the trade and investment in an international market by the misalignment which is directly effect on the cross of sustain issues. The currency undervaluation found and restrict import also effect on the investment policies with huge interaction of magnitude, and it across the currency and evidence of trade policy. Third, the fund evidence converts evidence of support and compensates for the overvalued currency policies. However, the policies seem to be anti-dumping intervention of international trade and investment.(Amoako, Cobbinah, \& Mensah Darkwah, 2019) The recent persistent of the panel data affirm the fact that financial development influence on growth and covariates of growth and the potential simultaneity, and unobserved country specific growth. Hence, the above countries indicators of financial development by regarding different expects of trade and 
monitoring policies and investment. (Frimpong Boamah \& Sumberg, 2019)The conclude on the positive influence between financial development on the economic growth with trade and implication of change in policies and strategies with global tradition change. The recent imbalance in non-traditional trade and the effect of exchange rate restrictive measure the international trade.(Brobbey, Pouliot, Hansen, $\&$ Kyereh, 2019) the presumption of investment indirectly in different public and private sectors are also showed the presumption of exchange rate with theoretical literature and trade investment. (Ayanoore, 2019; Gad et al., 2019) .

We effect the volatility of the relationship of investment and trade and policy on the regression estimate on the panel datasets of these countries and also in-touch with other different countries whose policies only interact with misalignment affect trade policies decision.(Sovacool, 2019) we also discuss The method framework in next section with a linear relationship of social inclusion and conversion factors change the implemented policies of nations, where the real price, trade, a technology, a price rate and price level of ratio taking an important part of growth.

The international trade could have driven by the different causality, which directly related with trade and their flow of exchange because we base the investment and trade on the proper finance policies with a legal interaction of foreign affairs.(Mullineux \& Murinde, 2014) Therefore, the exchange rate compelling the argument of risk association of forward contact and currency option. Another critique of related sunk cost in export and investment.(Alhassan \& Fiador, 2014) The higher fixed cost of investment and export are the volatility issues of international trade where the exchange rate is a a critical issue of international trade. The crossborder transaction of the international firm in Ghana held and monitoring by under the private contract and the involvement of government also based on that private firms so international market the investment is a flow on inside and not given directly benefit to individually to state.

\section{Methodology}

We base the paper method on World Bank indicators, which is undertaking in Ghana and focused on the critical issues of monitoring policies. In particular, the study sought to determine influence of exchange rate and global trade evidence by the Table 1, in which the trade policies has determine the social inclusion and equity with public resource, building human resources and social protection for economic development has determined. We have analysed the alternative DEC factors' annual exchange rate and also reported with IMF's international financial statistics by dollars. The exchange rate is determined by legal sanctioned and annual average income based. The purchasing power parity has been computed by a unit of the domestic market and the PPP conversion factor results got by the exchange rate of Ghana. The ratio also referred to the national level. The real price nominal effective 
rate and weighting average of several exchange rates are divided by a price deflator or index of cost. The merchandise trade as a share of GDP and merchandise exports with imports divided by the value of GDP in all current US. dollars. The high technology export targets the monitoring policies with high R\&D intensity. The travel service determined the service economy which is use during in one year and also include the good or services. Initially by the linear state we have computed the data in unit root and individually hypothesis each indicator.

Table 1: Indicators

\begin{tabular}{|c|c|c|c|}
\hline Country & & & \\
\hline Name & Indicator & Indicator Name & Indicator Code \\
\hline Ghana & CPIA & $\begin{array}{l}\text { CPIA policies for social inclusion/equity cluster } \\
\text { average ( } 1=\text { low to } 6=\text { high) } \\
\text { DEC alternative conversion factor (LCU per }\end{array}$ & IQ.CPA.SOCI.XQ \\
\hline Ghana & DEC & US\$) & PA.NUS.ATLS \\
\hline Ghana & LCU & $\begin{array}{l}\text { Official exchange rate (LCU per US\$, period } \\
\text { average) }\end{array}$ & PA.NUS.FCRF \\
\hline Ghana & PLR & $\begin{array}{l}\text { Price level ratio of PPP conversion factor (GDP) } \\
\text { to market exchange rate }\end{array}$ & PA.NUS.PPPC.RF \\
\hline Ghana & REX & Real effective exchange rate index $(2010=100)$ & PX.REX.REER \\
\hline Ghana & MT & Merchandise trade (\% of GDP) & TG.VAL.TOTL.GD.ZS \\
\hline Ghana & THE & $\begin{array}{l}\text { High-technology exports ( } \% \text { of manufactured } \\
\text { exports) }\end{array}$ & TX.VAL.TECH.MF.ZS \\
\hline Ghana & $\mathrm{TSC}$ & exports) & TX.VAL.TRVL.ZS.WT \\
\hline
\end{tabular}

\section{Results and Analysis}

Table 2: Mean deviation

\begin{tabular}{|lrlllllll}
\hline & CPIA & DEC & LCU & MT & PLR & REX & THE & TSC \\
Mean & 3.878571 & 0.829691 & 0.829399 & 54.82708 & 0.333163 & 335.0439 & 4.566921 & 25.94839 \\
Median & 3.9 & 0.18415 & 0.184172 & 54.08051 & 0.323188 & 109.9112 & 4.443817 & 8.795014 \\
Maximum & 4 & 4.5853 & 4.585325 & 93.19641 & 0.608276 & 3549.286 & 8.259932 & 77.20946 \\
Minimum & 3.7 & 0.000188 & 0.000115 & 25.3466 & 0.146365 & 64.66527 & 1.698087 & 0.347222 \\
Std. Dev. & 0.10509 & 1.248766 & 1.248978 & 15.22207 & 0.124527 & 676.9838 & 2.657452 & 27.5994 \\
& - & & & & & & & \\
Skewness & 0.387414 & 1.795421 & 1.794974 & 0.372768 & 0.184021 & 3.574841 & 0.363313 & 0.63838 \\
Kurtosis & 2.050271 & 5.268294 & 5.267016 & 3.177636 & 1.971886 & 15.61889 & 1.594373 & 1.676852 \\
Jarque-Bera & 0.876367 & 33.07204 & 33.04967 & 1.076859 & 1.440906 & 341.8259 & 0.730267 & 6.057327 \\
Probability & 0.645208 & 0 & 0 & 0.583664 & 0.486532 & 0 & 0.694104 & 0.04838 \\
Sum & 54.3 & 36.50641 & 36.49354 & 2412.391 & 9.66173 & 13066.71 & 31.96845 & 1115.781 \\
Sum Sq. Dev. & 0.143571 & 67.05493 & 67.07769 & 9963.595 & 0.434196 & 17415670 & 42.3723 & 31992.53 \\
Observations & 14 & 44 & 44 & 44 & 29 & 39 & 7 & 43
\end{tabular}


They indicate table 2 the mean deviation with a standard deviation and shows the highest mean value of REX with CPIA, which shows a significant impact on monitoring policies. Table 3 analysed the indicator summary with the different code where the person test value shows 0 . Table 4 is showing the test of equality. where the second highest deviation in MT.

Table 3: Tabulation summary of indicators

Tabulation Summary

Variable

Categories

CPIA

DEC

LCU

MT

PLR

REX

THE

TSC

Product of Categories

Test Statistics

Pearson X2

Likelihood Ratio G2

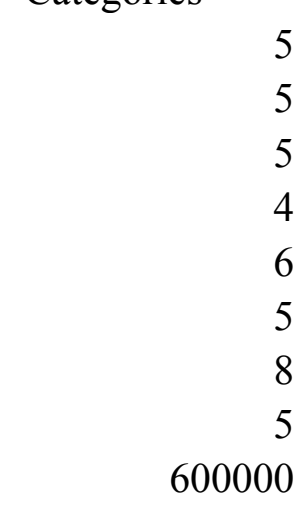

Table 4: Test of equality

Test for Equality of Means Between Series

Sample: 19752018

Included observations: 44

Method

df

Value

Probability

Anova F-test

$(7,256)$

df

$\begin{array}{lrr} & \text { Value } & \text { Prob } \\ 599964 & 6362469 & \\ 599964 & 420.7576 & \end{array}$


*Test allows for unequal cell variances

Source of Variation df

Between

Within

Total

Category Statistics
Sum of Sq. Mean Sq.

$\begin{array}{rrr}7 & 3475070 & 496438.5 \\ 256 & 17457804 & 68194.55 \\ 263 & 20932873 & 79592.67\end{array}$

Std. Err.

Std. Dev. of Mean

\begin{tabular}{lrrrr} 
Variable & Count & \multicolumn{1}{l}{ Mean } & Std. Dev. & of Mean \\
CPIA & 14 & 3.878571 & 0.10509 & 0.028087 \\
DEC & 44 & 0.829691 & 1.248766 & 0.188259 \\
LCU & 44 & 0.829399 & 1.248978 & 0.188291 \\
MT & 44 & 54.82708 & 15.22207 & 2.294814 \\
PLR & 29 & 0.333163 & 0.124527 & 0.023124 \\
REX & 39 & 335.0439 & 676.9838 & 108.4042 \\
THE & 7 & 4.566921 & 2.657452 & 1.004422 \\
TSC & 43 & 25.94839 & 27.5994 & 4.208869 \\
All & 264 & 63.4993 & 282.1217 & 17.36339
\end{tabular}

Table 5: Unit root test

Null Hypothesis: Unit root (common unit root process)

Series: CPIA, DEC, LCU, MT, PLR, REX, THE, TSC

Sample: 19752018

Exogenous variables: Individual effects

Automatic selection of maximum lags

Automatic lag length selection based on SIC: 0 to 4

Newey-West automatic bandwidth selection and Bartlett kernel

Total number of observations: 237

Cross-sections included: 8

Method

Levin, Lin \& Chu t*

** Probabilities are computed assuming asympotic normality

Intermediate results on D(UNTITLED)

\begin{tabular}{|c|c|c|c|c|c|c|c|c|}
\hline Series & $\begin{array}{l}\text { 2nd Stage } \\
\text { Coefficient }\end{array}$ & $\begin{array}{l}\text { Variance } \\
\text { of Reg }\end{array}$ & $\begin{array}{l}\text { HAC } \\
\text { of } \\
\text { Dep. }\end{array}$ & Lag & & $\begin{array}{l}\text { Max } \\
\text { Lag }\end{array}$ & $\begin{array}{l}\text { Band- } \\
\text { width }\end{array}$ & Obs \\
\hline $\mathrm{D}(\mathrm{CPIA})$ & -0.86486 & 0.0046 & 0.0037 & & 1 & 1 & 1 & \\
\hline $\mathrm{D}(\mathrm{DEC})$ & 0.54354 & 0.014 & 0.0148 & & 4 & 9 & 2 & \\
\hline $\mathrm{D}(\mathrm{LCU})$ & 0.54367 & 0.014 & 0.0148 & & 4 & 9 & 2 & \\
\hline $\mathrm{D}(\mathrm{MT})$ & -1.19398 & 133.81 & 6.8088 & & 0 & 9 & 41 & \\
\hline
\end{tabular}




$\begin{array}{lrrrrrrr}\text { D(PLR) } & -1.08333 & 0.0036 & 0.0005 & 0 & 5 & 13 & 27 \\ \mathrm{D} \text { (REX) } & -1.22533 & 281967 & 46476 & 0 & 9 & 26 & 37 \\ \mathrm{D} \text { (THE) } & -2.31254 & 0.4467 & 15.284 & 0 & 0 & 2 & 3 \\ \mathrm{D} \text { (TSC) } & -1.0286 & 122.17 & 24.487 & 0 & 9 & 10 & 41\end{array}$

\begin{tabular}{|c|c|c|c|c|c|c|}
\hline & Coefficient & t-Stat & $\begin{array}{l}\text { SE } \\
\text { Reg }\end{array}$ & $\mathrm{mu}^{*}$ & sig* & Obs \\
\hline ooled & -1.13345 & -13.579 & 1.318 & -0.548 & 0.895 & 237 \\
\hline
\end{tabular}

It indicates table 5 the unit root test for the stationary factor individual and with $2^{\text {nd }}$ coefficient determined the variance of HAC. The least squares are shown in Table 6 with the dependent variable. The other two variables exclude a cause of a unit root. Fig 1 is showing the mean deviation of individual variables.
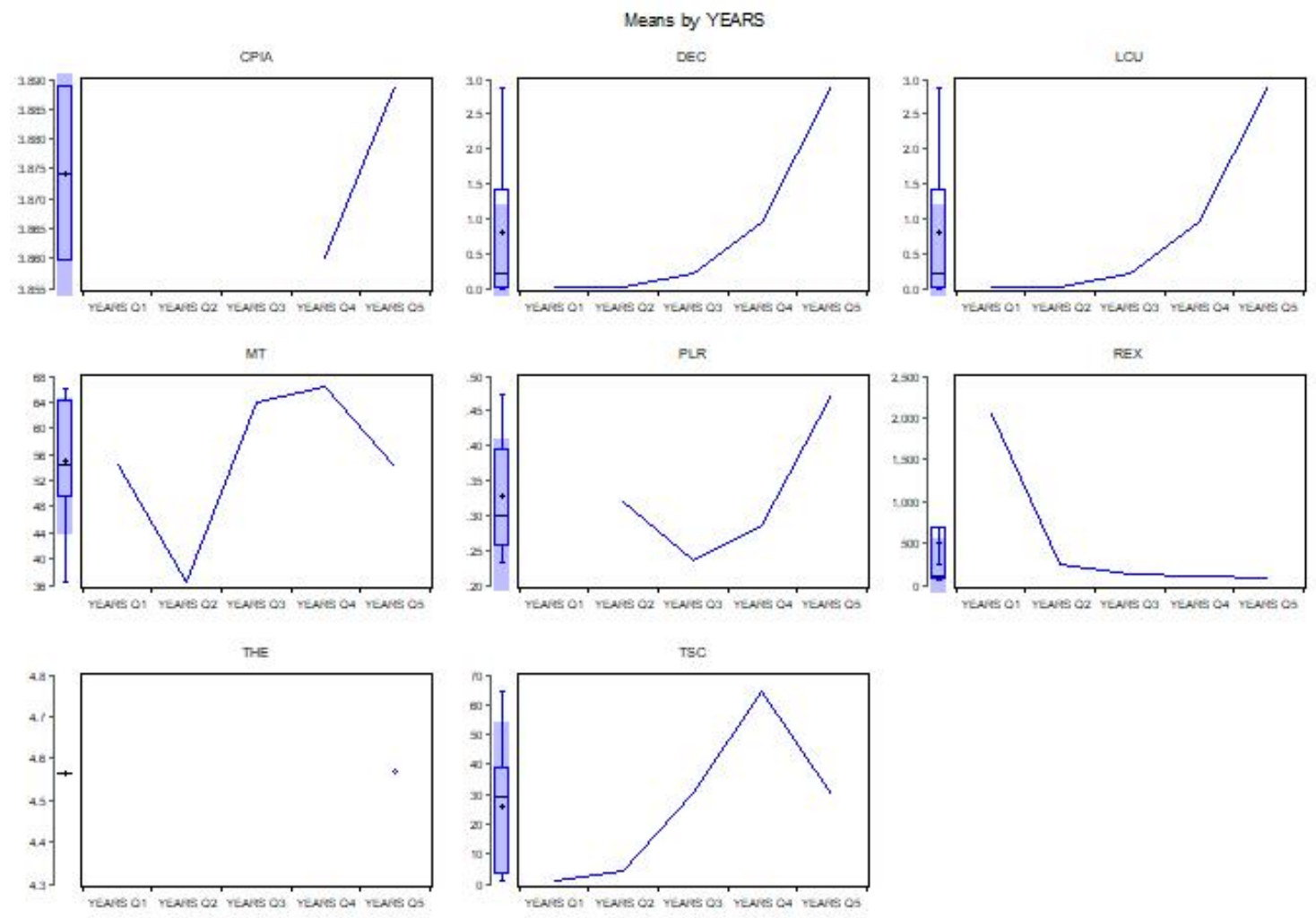

Figure 1: Mean deviation

Table 6: Least square

Dependent Variable: DEC

Method: Least Squares

Sample (adjusted): 19902017

Included observations: 28 after adjustments

Prob. 


$\begin{array}{lrcrr}\text { LCU } & 0.99996 & 1.35 \mathrm{E}-05 & 73956.32 & 0 \\ \text { MT } & -1.71 \mathrm{E}-06 & 9.22 \mathrm{E}-07 & -1.853493 & 0.0773 \\ \text { PLR } & 2.33 \mathrm{E}-05 & 9.32 \mathrm{E}-05 & 0.250096 & 0.8048 \\ \text { REX } & -1.19 \mathrm{E}-06 & 6.30 \mathrm{E}-07 & -1.886635 & 0.0725 \\ \text { TSC } & 4.07 \mathrm{E}-07 & 3.29 \mathrm{E}-07 & 1.238736 & 0.2285 \\ \text { C } & 0.000249 & 0.000138 & 1.80822 & 0.0843 \\ \text { R-squared } & 1 & \text { Mean dependent var } & 1.136611 \\ \text { Adjusted R- } & 1 & \text { S.D. dependent var } & 1.21936 \\ \text { squared } & & & -17.4304 \\ \text { S.E. of } & \text { regression } & 3.61 \mathrm{E}-05 & \text { Akaike info criterion } & -17.14493 \\ \text { Sum } & & & -17.34313 \\ \text { squared reside } & 2.87 \mathrm{E}-08 & \text { Schwarz criterion } & 1.987947 \\ \text { Log likelihood } & 250.0257 & \text { Hannan-Quinn criter. } & \\ \text { F-statistic } & 6.14 \mathrm{E}+09 & \text { Durbin-Watson stat } & \\ \text { Prob(F-statistic) } & 0 & & \end{array}$

Table 7: Ramsey Test

Ramsey RESET Test

Equation: UNTITLED

Specification: DEC LCU MT PLR REX TSC C

Omitted Variables: Squares of fitted values

\begin{tabular}{llrr} 
& Value & df & \multicolumn{2}{c}{ Probability } \\
t-statistic & 0.836358 & 21 & 0.4124 \\
F-statistic & 0.699494 & $(1,21)$ & 0.4124 \\
Likelihood ratio & 0.917463 & 1 & 0.3381
\end{tabular}

F-test summary:

$\begin{array}{llrrr} & \begin{array}{l}\text { Sum of } \\ \text { Sq. }\end{array} & \text { df } & & \text { Mean Squares } \\ \text { Test SSR } & 9.27 \mathrm{E}-10 & & 1 & 9.27 \mathrm{E}-10 \\ \text { Restricted SSR } & 2.87 \mathrm{E}-08 & & 22 & 1.31 \mathrm{E}-09 \\ \text { Unrestricted } & & & & \\ \text { SSR } & 2.78 \mathrm{E}-08 & & 21 & 1.32 \mathrm{E}-09\end{array}$

LR test summary:

Value

Restricted $\operatorname{LogL} \quad 250.0257$

Unrestricted

LogL $\quad 250.4844$ 
Table 7 shows the test of restricted SSR and mean square with the 22 number of observation and tabulation of indicators has determined in Fig 2. T-test has computed in Table 8 and Table 9 is showing the ranger causality. The covariance relationship showing the relationship between indicators. Table 10 shows the residual factor individually determined in Fig 3.

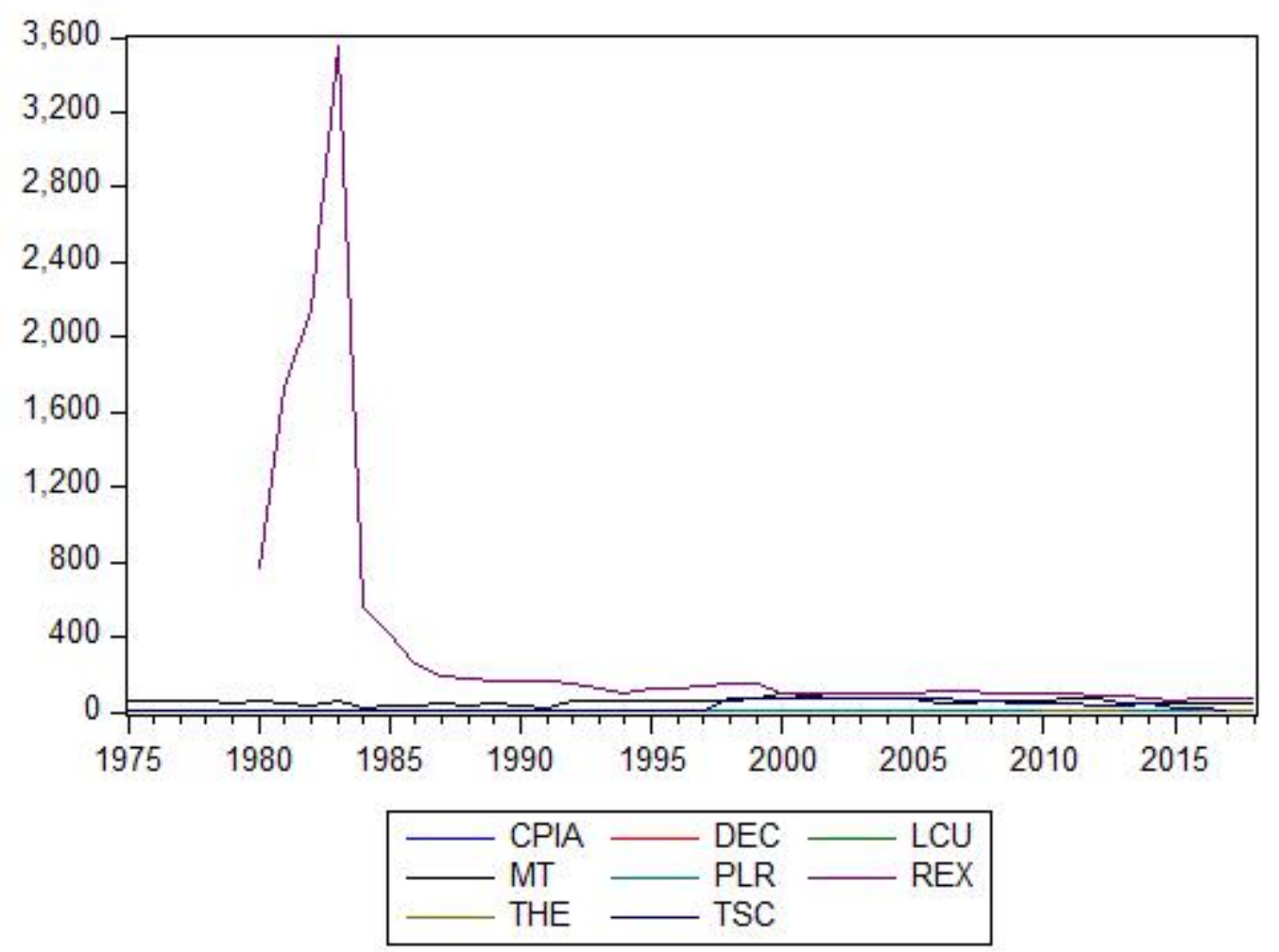

Figure 2: Tabulation of indicator

Table 8: t-test

Unrestricted Test Equation:

Dependent Variable: DEC

Method: Least Squares

Date: 11/23/19 Time: 17:01

Sample: 19902017

Included observations: 28

$\begin{array}{lrrrr}\text { Variable } & \text { Coefficient } & \text { Std.Error } & \text { t-Statistic } & \text { Prob. } \\ \text { LCU } & 1.000011 & 6.24 \mathrm{E}-05 & 16020.65 & 0 \\ \text { MT } & -1.88 \mathrm{E}-06 & 9.50 \mathrm{E}-07 & 1.976053 & 0.0614 \\ & & & - & \\ \text { PLR } & -7.64 \mathrm{E}-05 & 0.000152 & 0.503698 & 0.6197\end{array}$




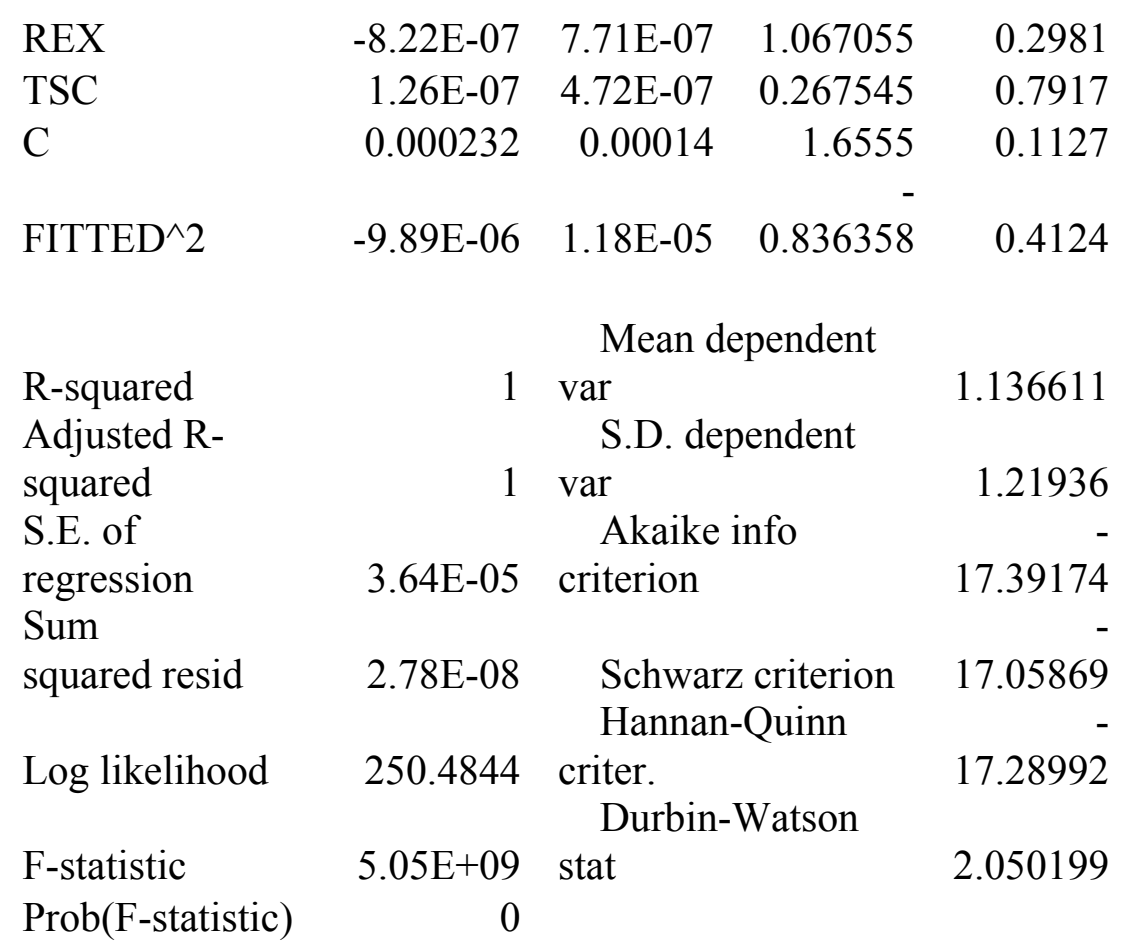

Table 9: Granger Causality

Pairwise Granger Causality Tests

Date: $11 / 23 / 19$ Time: $16: 55$

Sample: 19752018

Lags: 2

F-

Null Hypothesis: Obs Statistic Prob.

DEC does not 0.0067

CPIA does not Granger

Cause DEC

1.35528

0.318

LCU does not

Granger Cause CPIA $12 \quad 11.13$

0.0067

CPIA does not Granger

Cause LCU

1.35531

0.318

MT does not

Granger Cause CPIA $12 \quad 1.86558$

0.2242

CPIA does not Granger

Cause MT

0.17201

0.8454

PLR does not

Granger Cause CPIA $\quad 12 \quad 2.28497$

0.1723 
CPIA does not Granger

Cause PLR

0.46151

0.6482

REX does not

Granger Cause CPIA

$12 \quad 7.15632$

0.0203

CPIA does not Granger

Cause REX

1.32846

0.3243

THE does not

Granger Cause CPIA

CPIA does not Granger

Cause THE

3 NA

NA

NA NA

TSC does not

$\begin{array}{lll}\text { Granger Cause CPIA } & 11 & 2.14637\end{array}$

0.1981

CPIA does not Granger

Cause TSC

1.40867

0.3151

LCU does not

Granger Cause DEC

$42 \quad 0.07055$

0.932

DEC does not Granger

Cause LCU

0.06758

0.9348

MT does not

Granger Cause DEC

$42 \quad 0.36388$

0.6974

DEC does not Granger

Cause MT

0.21054

0.8111

PLR does not

Granger Cause DEC

$27 \quad 6.6503$

0.0055

DEC does not Granger

Cause PLR

0.93937

0.406

REX does not

Granger Cause DEC

$37 \quad 0.06702$

0.9353

DEC does not Granger

Cause REX

0.0858

0.918

THE does not

Granger Cause DEC

3 NA

NA

DEC does not Granger

Cause THE

NA

NA

TSC does not

Granger Cause DEC

$41 \quad 2.30762$

0.114

DEC does not Granger

Cause TSC

1.88969

0.1658 
MT does not

Granger Cause LCU

$42 \quad 0.35945$

0.7005

LCU does not Granger

Cause MT

0.20806

0.8131

PLR does not

Granger Cause LCU

$27 \quad 6.65019$

0.0055

LCU does not Granger

Cause PLR

0.93944

0.406

REX does not

Granger Cause LCU

$\begin{array}{lll}37 & 0.06546 & 0.9368\end{array}$

Cause REX

0.08564

0.9181

THE does not

Granger Cause LCU

LCU does not Granger

Cause THE

3 NA

NA

NA NA

TSC does not

Granger Cause LCU

$41 \quad 2.31138$

0.1137

LCU does not Granger

Cause TSC

1.89108

0.1656

PLR does not

Granger Cause MT

27

2.48218

0.1066

MT does not Granger Cause

PLR

1.36785

0.2755

REX does not

Granger Cause MT 37

2.15837

MT does not Granger Cause

REX

1.70868

0.1972

THE does not

Granger Cause M

MT does not Granger Cause

THE

3 NA

NA

NA NA

TSC does not

Granger Cause MT 41

2.24547

0.1205

MT does not Granger Cause

TSC

0.97516

0.3869

REX does not

Granger Cause PLR

$27 \quad 2.37232$

0.1167

PLR does not Granger

Cause REX 
THE does not

Granger Cause PLR 3 NA NA

PLR does not Granger

Cause THE

NA NA

TSC does not

Granger Cause PLR

$26 \quad 1.39125$

0.2708

PLR does not Granger

Cause TSC

2.49123

0.1069

THE does not

Granger Cause REX

3 NA NA

REX does not Granger

Cause THE

NA NA

TSC does not

Granger Cause REX
REX does not Grange

$36 \quad 0.20672$

0.8144

Cause TSC

0.0816

0.9218

TSC does not

Granger Cause THE

2 NA

NA

THE does not Granger

Cause TSC

NA NA

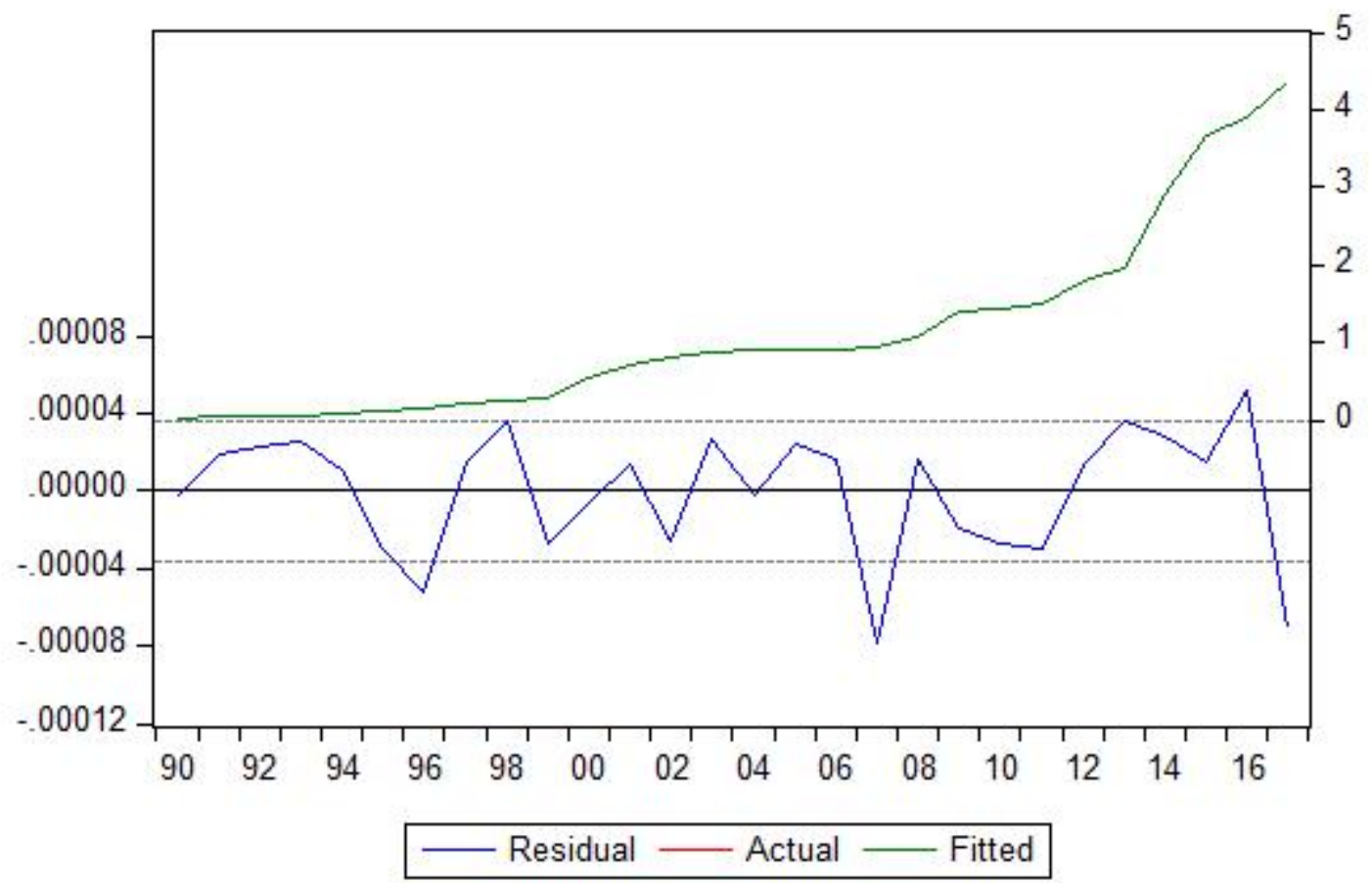

Figure 3: Residual 
Covariance Analysis: Ordinary (uncentered)

Sample: 20102017

Included observations: 6

Balanced sample (listwise missing value deletion)

Covariance

SSCP

$\mathrm{t}-$

Statistic CPIA DEC LCU MT PLR REX THE TSC

CPIA $\quad 15.34833$

92.09

DEC $\quad 9.66819 \quad 7.598494$

$58.00914 \quad 45.59096$

4.493159

$\begin{array}{llll}\text { LCU } & 9.668307 & 7.598604 & 7.598713 \\ & 58.00984 & 45.59162 & 45.59228 \\ & 4.493104 & 117827.1 & ----\end{array}$

$\begin{array}{lllll}\text { MT } & 225.082 & 131.755 & 131.7567 & 3439.153\end{array}$

$\begin{array}{llrr}1350.492 & 790.5298 & 790.54 & 20634.92\end{array}$

$10.92232 \quad 3.145414 \quad 3.145399 \quad----$

$\begin{array}{llllll}\text { PLR } & 1.875342 & 1.184778 & 1.184791 & 27.16776 & 0.232391 \\ & 11.25205 & 7.108668 & 7.108743 & 163.0065 & 1.394348 \\ 18.76971 & 4.402432 & 4.402349 & 7.769044 & -----\end{array}$

$\begin{array}{lllllll}\text { REX } & 337.3352 & 203.5599 & 203.5624 & 5006.151 & 41.08372 & 7485.076\end{array}$

$\begin{array}{lllllll}2024.011 & 1221.36 & 1221.374 & 30036.91 & 246.5023 & 44910.46\end{array}$

$\begin{array}{lllllll}22.86413 & 3.6633 & 3.663269 & 13.56715 & 12.78949 & -----\end{array}$

\begin{tabular}{lrrrrrrrr} 
THE & 15.55299 & 9.702807 & 9.702915 & 232.7672 & 1.908802 & 335.1828 & 20.02387 & \\
& 93.31795 & 58.21684 & 58.21749 & 1396.603 & 11.45281 & 2011.097 & 120.1432 & \\
& 4.299181 & 2.848676 & 2.848651 & 4.29513 & 4.247352 & 3.868671 & ----- & \\
\multirow{2}{*}{ TSC } & & & & & & & & \\
& 117.712 & 60.10517 & 60.10579 & 1801.242 & 14.37304 & 2685.906 & 112.8893 & 1053.608 \\
& 706.2722 & 360.631 & 360.6348 & 10807.45 & 86.23826 & 16115.44 & 677.3357 & 6321.647 \\
& 5.470541 & 2.027712 & 2.027697 & 6.542025 & 5.195568 & 7.325082 & 2.761902 & -----
\end{tabular}

\section{Conclusion.}


The results have been signifying the relationship and influence of monitoring policy on trade and foreign policies. We classify the above results in Table5-7. Therefore, the highly effected PLR has been creating influence on THE, MT and TSC (Table 8) and showed a significant influence on the growth and internal policies of government issues. The method of the real price shows the nominal effective rate and weighting average of several exchange rates and it is divided by a price deflator or index of cost. Also, the monitoring policies monitoring policies with high R\&D intensity. The travel service determined the service economy which used during in one year and also include the good or services. The expected outcomes of public policies and practice showed the influence of monitoring policies with comprehensive pioneering strategies of exchange rate, the non-linarite and pass through effect the volatility of Ghana's. $2^{\text {nd }}$ the economic growth and ramifications of global competitiveness is shows the significant effects on the poverty reduction and growing economic wealth. The relevance of this study is serve as powerful strategical tools which showing the practicality effect sluggish growth rate. However, the government has taken reserve, but the policies can change the magnitude of strength and policies. In we include last the exchange rate volatility to estimating growth under the control of endogenous and resulting of simulating lag dependency so, the yield estimation shows above the robustness and stability test by liner square and restricted with SSR and mean square. The tabulation of indicators determined T-test computed in granger causality. The prior most studies are showing the potential simultaneity, and unobserved country specific growth regarding the financial department and trade in monitoring policies. Therefore, the tragic policies of government control the inflation situation by proper monitoring policies in exchange rates.

\section{Uncategorized References}

Acheampong, E., \& Maryudi, A. (2020). Avoiding legality: Timber producers' strategies and motivations under FLEGT in Ghana and Indonesia. Forest Policy and Economics, 111, 102047. doi:https://doi.org/10.1016/j.forpol.2019.102047

Adom, P. K., \& Kwakwa, P. A. (2014). Effects of changing trade structure and technical characteristics of the manufacturing sector on energy intensity in Ghana. Renewable and Sustainable Energy Reviews, 35, 475-483. doi:https://doi.org/10.1016/j.rser.2014.04.014

Adu, G., Marbuah, G., \& Mensah, J. T. (2013). Financial development and economic growth in Ghana: Does the measure of financial development matter? Review of Development Finance, 3(4), 192-203. doi:https://doi.org/10.1016/j.rdf.2013.11.001

Agusto, F. B., \& Khan, M. A. (2018). Optimal control strategies for dengue transmission in pakistan. Mathematical Biosciences, 305, 102-121. doi:https://doi.org/10.1016/j.mbs.2018.09.007 
Ahmed, A., Korah, P. I., Dongzagla, A., Nunbogu, A. M., Niminga-Beka, R., Kuusaana, E. D., \& Abubakari, Z. (2020). City profile: Wa, Ghana. Cities, 97, 102524. doi:https://doi.org/10.1016/j.cities.2019.102524

Alhassan, A. L., \& Fiador, V. (2014). Insurance-growth nexus in Ghana: An autoregressive distributed lag bounds cointegration approach. Review of Development Finance, 4(2), 83-96. doi:https://doi.org/10.1016/j.rdf.2014.05.003

Amoako, C., Cobbinah, P. B., \& Mensah Darkwah, R. (2019). Complex twist of fate: The geopolitics 11 Geopolitics is used in this paper to refer to the way that geography of vulnerable communities affects political interventions in terms of flood management regimes of flood management regimes in Accra, Ghana. Cities, 89, 209-217. doi:https://doi.org/10.1016/j.cities.2019.02.006

Amri, F. (2017). Intercourse across economic growth, trade and renewable energy consumption in developing and developed countries. Renewable and Sustainable Energy Reviews, 69, 527-534. doi:https://doi.org/10.1016/j.rser.2016.11.230

Ayanoore, I. (2019). The politics of local content implementation in Ghana's oil and gas sector. The Extractive Industries and Society. doi:https://doi.org/10.1016/j.exis.2019.11.004

Bond, S. R., Söderbom, M., \& Wu, G. (2011). Pursuing the wrong options? Adjustment costs and the relationship between uncertainty and capital accumulation. Economics Letters, 111(3), 249-251. doi:https://doi.org/10.1016/j.econlet.2011.01.020

Brobbey, L. K., Pouliot, M., Hansen, C. P., \& Kyereh, B. (2019). Factors influencing participation and income from charcoal production and trade in Ghana. Energy for Sustainable Development, 50, 69-81. doi:https://doi.org/10.1016/j.esd.2019.03.003

Frimpong Boamah, E., \& Sumberg, J. (2019). The long overhang of bad decisions in agro-industrial development: Sugar and tomato paste in Ghana. Food Policy, 89, 101786. doi:https://doi.org/10.1016/j.foodpol.2019.101786

Gad, M., Lord, J., Chalkidou, K., As are, B., Lettered, M. G., \& Ruiz, F. (2019). Supporting the Development of Evidence-Informed Policy Options: An Economic Evaluation of Hypertension Management in Ghana. Value in Health. doi:https://doi.org/10.1016/j.jval.2019.09.2749

Herrerias, M. J., Cuadros, A., \& Luo, D. (2016). Foreign versus indigenous innovation and energy intensity: Further research across Chinese regions. Applied Energy, 162, 1374-1384. doi:https://doi.org/10.1016/j.apenergy.2015.01.042

Khanal, P. N., Grebner, D. L., Straka, T. J., \& Adams, D. C. (2019). Obstacles to participation in carbon sequestration for nonindustrial private forest landowners in the southern United States: A diffusion of innovations perspective. Forest Policy and Economics, 100, 95-101. doi:https://doi.org/10.1016/j.forpol.2018.11.007 
Kong, Y., \& Khan, R. (2019). To examine environmental pollution by economic growth and their impact in an environmental Kuznets curve (EKC) among developed and developing countries. PloS one, 14(3). doi:https://doi.org/10.1371/journal.pone.0209532

Lin, B., \& Agyeman, S. D. (2019). Assessing Ghana's carbon dioxide emissions through energy consumption structure towards a sustainable development path. Journal of Cleaner Production, 238, 117941. doi:https://doi.org/10.1016/j.jclepro.2019.117941

Mensah, J. T., \& Botchway, E. (2013). Ghana's salt industry: A neglected sector for economic development? Resources Policy, 38(3), 288-294. doi:https://doi.org/10.1016/j.resourpol.2013.06.002

Mullineux, A. W., \& Murinde, V. (2014). Financial sector policies for enterprise development in Africa. Review of Development Finance, 4(2), 66-72. doi:https://doi.org/10.1016/j.rdf.2014.05.001

Murtazashvili, I., Murtazashvili, J., \& Salahodjaev, R. (2019). Trust and deforestation: A cross-country comparison. Forest Policy and Economics, 101, 111-119. doi:https://doi.org/10.1016/j.forpol.2019.02.001

Sovacool, B. K. (2019). Toxic transitions in the lifecycle externalities of a digital society: The complex afterlives of electronic waste in Ghana. Resources Policy, 64, 101459. doi:https://doi.org/10.1016/j.resourpol.2019.101459

Traoré, S. (2019). Residential location choice in a developing country: What matter? A choice experiment application in Burkina Faso. Forest Policy and Economics, 102, 1-9. doi:https://doi.org/10.1016/j.forpol.2019.01.021

Uddin, G. S., Sjö, B., \& Shahbaz, M. (2013). The causal nexus between financial development and economic growth in Kenya. Economic Modelling, 35, 701707. doi:https://doi.org/10.1016/j.econmod.2013.08.031 